\title{
ANALISIS NILAI TAMBAH PENGOLAHAN KELAPA MENJADI VIRGIN COCONUT OIL DI KABUPATEN NIAS SELATAN, PROVINSI SUMATERA UTARA
}

\author{
The Value Added Analysis on Coconut Processing into Virgin Coconut Oil in South Nias \\ Regency, North Sumatra Province
}

\author{
Diego Mendes Pereira ${ }^{1)}$ \\ I Gusti Agung Ayu Ambarawati ${ }^{2)}$ \\ I Wayan Budiasa ${ }^{3)}$
}

\author{
Fakultas Pertanian, Universitas Udayana, Bali, Indonesia \\ Email: mp.diego2013@gmail.com ${ }^{1)}$ \\ annie.ambarawati@unud.ac.id ${ }^{2)}$
}

\begin{abstract}
As a country that has the largest coconut plantations in the world, Indonesia has the potential and opportunity to become a world leader in the production of processed coconut. South Nias Regency has good potential in coconut processing, but has not been utilized optimally. The only coconut processing company producing Virgin Coconut Oil (VCO) in South Nias Regency is CV Ononiha Oil, and this company provides guidance to the surrounding coconut farmers. The purpose of this study is to determine the added value, labor benefits, and profit of processing coconut into VCO, and to analyze the production and marketing constraints of VCO in South Nias Regency. This research was conducted in South Nias Regency, North Sumatra Province, with coconut processing farmers into VCO and the company CV Ononiha Oil. The determination of key respondents was carried out through purposive sampling, namely the owner of the CV Ononiha Oil and ten respondent farmers were chosen using the census method. Value added analysis in this study uses the Hayami method. The results showed that the added value, labor benefits, and the highest profits were at the farm level, where farmers get added value of $R p 9.522$ while the company gets an added value of $R p 4.833$ in one production process cycle; farmers' labor compensation is $R p$ 3.389, compared to the company only $R p$ 960; profit at the farmer level is $R p$ 6.132, while at the company is Rp 3.873. The obstacles faced by farmers are the limited absorption of the local market and the lack of permission from PIRT (Pangan Industri Rumah Tangga - Home Industry Food) to enter larger markets such as supermarkets or markets outside the district. The constraints that exist on both the farmer and the company CV Ononiha Oil are on the management and marketing side which is less efficient, and has not yet obtained an organic certificate. Farmers and companies are expected to be able to enter the broader market by certifying their products and improving management capabilities.
\end{abstract}

Keywords: virgin coconut oil, added value, coconut, Nias 


\section{ABSTRAK}

Sebagai negara yang memiliki perkebunan kelapa terbesar di dunia, Indonesia memiliki potensi dan peluang untuk menjadi pemimpin dunia dalam produksi kelapa olahan. Kabupaten Nias Selatan memiliki potensi yang baik dalam pengolahan kelapa, tetapi belum dimanfaatkan secara optimal. Satu-satunya perusahaan pengolahan kelapa yang memproduksi Virgin Coconut Oil (VCO) di Kabupaten Nias Selatan adalah CV Ononiha Oil, dan perusahaan ini memberikan panduan kepada para petani kelapa di sekitarnya. Tujuan dari penelitian ini adalah untuk menentukan nilai tambah, manfaat tenaga kerja, dan laba dari pengolahan kelapa menjadi VCO, dan untuk menganalisis kendala produksi dan pemasaran VCO di Kabupaten Nias Selatan. Penelitian ini dilakukan di Kabupaten Nias Selatan, Provinsi Sumatera Utara, dengan petani pengolah kelapa menjadi VCO dan perusahaan CV Ononiha Oil. Penentuan responden kunci dilakukan melalui purposive sampling, yaitu pemilik CV Ononiha Oil dan sepuluh petani responden dipilih menggunakan metode sensus. Analisis nilai tambah dalam penelitian ini menggunakan metode Hayami. Hasil penelitian menunjukkan bahwa nilai tambah, manfaat tenaga kerja, dan laba tertinggi berada di tingkat petani, di mana petani mendapat nilai tambah Rp 9,522 sedangkan perusahaan mendapat nilai tambah $\mathrm{Rp} 4,833$ dalam satu siklus proses produksi; kompensasi tenaga kerja petani adalah Rp3.389, dibandingkan dengan perusahaan hanya Rp960; keuntungan di tingkat petani adalah Rp 6.132, sementara di perusahaan adalah Rp 3.873. Hambatan yang dihadapi oleh petani adalah terbatasnya penyerapan pasar lokal dan kurangnya izin dari PIRT (Pangan Industri Rumah Tangga) untuk memasuki pasar yang lebih besar seperti supermarket atau pasar di luar kabupaten. Kendala yang ada pada petani dan perusahaan CV Ononiha Oil adalah pada sisi manajemen dan pemasaran yang kurang efisien, dan belum mendapatkan sertifikat organik. Petani dan perusahaan diharapkan dapat memasuki pasar yang lebih luas dengan mensertifikasi produk mereka dan meningkatkan kemampuan manajemen.

Kata Kunci: minyak kelapa murni, nilai tambah, kelapa, Nias

\section{PENDAHULUAN}

\section{Latar Belakang}

Indonesia memiliki perkebunan kelapa dalam (Cocos nucifera) terluas di dunia, dengan luas areal mencapai 3,5 juta hektar (ha) dan produksi mencapai 18,3 juta ton buah kelapa, yang berarti sekitar 30\% dari total produksi dunia. Melalui pengolahan kelapa menjadi Virgin Coconut Oil (VCO), penambahan nilai kelapa Indonesia bisa mencapai potensi maksimal, Direktur Jenderal Perkebunan (2017). Sejak sepuluh tahun yang lalu, Direktorat Jenderal Industri Agro dan Kimia Departemen Perindustrian Jakarta (2009), sudah menyatakan bahwa "Potensi tersebut perlu diolah dan menjadi produk akhir supaya bisa diekspor ke seluruh dunia dengan nilai yang baik, bukan hanya jual bahan mentah dengan nilai jual dan pendapatan yang rendah."

Berdasarkan jumlah luas areal perkebunan kelapa di Indonesia, wilayah Sumatera memiliki sekitar 30\% dengan luas total sebesar 1,1 juta Ha kebun kelapa. Sumatera juga memiliki lokasi geografis lebih dekat dari beberapa negara konsumen, seperti Singapura, Cina, dan Jepang. Provinsi Sumatera Utara yang beribukotakan Medan, adalah salah satu daerah yang memiliki luas areal perkebunan kelapa terbesar di Wilayah Sumatera. Medan merupakan 
kota paling besar di luar Jawa dan memiliki pelabuhan internasional Belawan, pelabuhan terbesar di Indonesia di luar Jawa (BPS, 2017). Hal ini menunjukkan bahwa Sumatera Utara memiliki fasilitas infrastruktur dan pelabuhan internasional yang mumpuni untuk ekspor.

Kabupaten Nias Selatan yang terletak di Sumatera Utara adalah daerah strategis untuk memproduksi, mengolah dan memasarkan hasil olahan kelapa untuk pasar lokal dan pasar Internasional. Salah satu penyebabnya karena harga buah kelapa dan tenaga kerja tergolong murah dibandingkan kota besar seperti Medan. Selain itu, pembangunan usahatani kelapa akan menguatkan kemajuan di daerah Nias Selatan dan pembangunan pertanian yang berkelanjutan di daerah Nias Selatan, Kabupaten Nias Selatan adalah kabupaten di Sumatera Utara yang memiliki potensi dan produksi kelapa terbesar kedua setelah Kabupaten Asahan (BPS, 2017).

Walaupun potensi kelapa cukup besar di Kabupaten Nias Selatan, namun hanya terdapat satu perusahaan yaitu CV Ononiha Oil dan sepuluh petani pengolah kelapa menjadi VCO skala rumah tangga di Kabupaten Nias Selatan. Petani pengolah memproduksi VCO skala rumah tangga dan memasarkan kepada masyarakat lokal, dan perusahaan memproduksi VCO dengan jumlah 6 ton per bulan untuk pasar domestik dan internasional (Matias Wau, manager CV Ononiha Oil, komunikasi pribadi, 2018).

VCO adalah produk kelapa bernilai tinggi terbaru yang tendensi permintaannyq akan terus meningkat, karena market mencari produk yang sehat dan bermanfaatnya bagi manusia, nutraceutical dan sebagai makanan fungsional (FAO, 2006). Nester (2017) menyatakan pasar minyak kelapa global memperoleh pendapatan signifikan pada tahun sebelumnya, dan diperkirakan akan meningkat pada Compound Annual Growth Rate (CAGR) sekitar $11 \%$ selama periode perkiraan. Penambahan nilai dengan pengolahan kelapa menjadi VCO masih memiliki potensi yang besar di tingkat rumah tangga dan tingkat perusahaan.

\section{Tujuan Penelitian}

Penelitian ini bertujuan untuk menganalisis dan mengetahui nilai tambah, imbalan tenaga kerja, dan keuntungan pengolahan kelapa menjadi Virgin Coconut Oil (VCO) di tingkat perusahaan dan tingkat petani di Kabupaten Nias Selatan, serta mengetahui kendalakendala dalam produksi dan pemasaran VCO di Kabupaten Nias Selatan

\section{METODOLOGI PENELITIAN}

Penelitian ini dilakukan di Kabupaten Nias Selatan, Provinsi Sumatera Utara. Waktu penelitian telah dilakukan pada bulan Agustus 2019 sampai dengan bulan September 2019. Pengumpulan data dalam penelitian ini dilakukan melalui beberapa metode yaitu: (1) Wawancara dengan bantuan instrumen kuesioner semi terstruktur, (2) Pengamatan atau observasi, (3) Dokumentasi, dan (4) Studi pustaka.

Analisis data menggunakan analisis nilai tambah. Penelitian nilai tambah pengolahan kelapa menjadi VCO telah dilakukan dengan dua pendekatan analisis, yaitu 1) Analisis deskriptif untuk mendeskripsikan gambar proses pengolahan kelapa menjadi VCO di Kabupaten Nias Selatan, proses pengolahan telah dilihat dan dibandingkan antara petani dan perusahaan, untuk mendapati kendala-kendala di dalam proses pengolahan dan 
pemasaran kelapa menjadi VCO; 2) Metode Hayami et al., (1987) digunakan untuk analisis nilai tambah, imbalan tenaga kerja, dan keuntungan pengolahan kelapa menjadi VCO. Perhitungan nilai tambah dilakukan pada perusahaan CV Ononiha Oil dan juga seluruh petani yang melakukan pengolahan kelapa menjadi VCO di skala rumah tangga. Selanjutnya hasil perhitungan nilai tambah dibandingkan antara perusahaan dan petani untuk melihat praktik mana yang lebih menguntungkan sekaligus dapat dilakukan secara berkelanjutan.

\section{HASIL DAN PEMBAHASAN}

\section{Karakteristik Perusahaan dan Petani Pengolah Kelapa Menjadi VCO}

Perusahaan CV Ononiha Oil mulai berproduksi pada tahun 2006 dengan 18 orang karyawan. Perusahaan masih termasuk perusahaan kecil dan memiliki struktur organisasi yang dipimpin langsung oleh pemiliknya. Pemilik perusahaan tersebut merangkap menjadi operational manager, marketing manager, financial manager dan sales manager. Pemilik menyusun seluruh perencanaan yang akan dijalankan di dalam perusahaan tersebut dan mengkoordinasikan seluruh perencanaan tersebut langsung kepada karyawan. Target pasar perusahaan CV Ononiha Oil merupakan pasar luar negeri, sekitar 90\% dari hasil pengolahan terjual ke pasar luar dan $10 \%$ di dalam negeri.

Petani pengolah kelapa menjadi VCO berusia berkisar antara 25-46 tahun dengan rata-rata usia 39 tahun, yang berarti usia petani responden tergolong pada usia produktif. Sebagian besar petani merupakan tamatan SMP (50\%), tamatan Perguruan Tinggi 40\%, dan tamatan SMA $10 \%$ dari total responden. Hal ini mempengaruhi bagaimana pandangan petani terhadap perubahan kegiatan pengolahan kelapa menjadi VCO dan keputusan untuk pemasaran VCO, rata-rata petani-petani yang memiliki pendidikan lebih tinggi dapat mengerti dan melanjutkan produksi VCO dengan lebih baik.

\section{Analisis Nilai Tambah VCO}

Nilai tambah adalah selisih antara nilai output dikurangi harga bahan baku dan sumbangan input lain. Dasar perhitungan metode analisis nilai tambah ini menggunakan perhitungan kilogram bahan baku daging kelapa.

\section{Analisis Nilai Tambah VCO di Tingkat Perusahaan}

Rata-rata nilai tambah perusahaan CV Ononiha Oil sebesar Rp 4.833 per kg bahan baku di dalam satu siklus produksi. Satu siklus produksi rata-rata menghasilkan $20 \mathrm{~kg} \mathrm{VCO}$, dari $150 \mathrm{~kg}$ bahan baku daging kelapa, dengan jumlah tersebut nilai tambah di dalam satu siklus produksi menghasilkan Rp 96.660, dan di dalam satu hari kerja perusahaan dapat mengolah rata-rata 12,5 siklus produksi. Hal ini berarti di dalam satu hari hasil nilai tambah berjumlah $\mathrm{Rp}$ 1.208.250. Nilai tambah tersebut masih merupakan nilai tambah kotor, karena masih mengandung imbalan tenaga kerja per kg bahan baku kelapa.

Tabel 1. Perhitungan nilai tambah perusahaan CV Ononiha Oil

\begin{tabular}{|c|c|c|c|}
\hline $\mathrm{No}$ & Variabel & Satuan & Nilai \\
\hline 1 & Output VCO & A $\quad$ (kg/siklus) & 20 \\
\hline 2 & Input Bahan Baku & B ( $\mathrm{kg} /$ siklus $)$ & 150 \\
\hline 3 & Input Tenaga Kerja & C (HOK/siklus) & 1.44 \\
\hline
\end{tabular}




\begin{tabular}{|c|c|c|c|c|}
\hline 4 & Faktor Konversi VCO & $\mathrm{D}=\mathrm{A} / \mathrm{B}$ & \multicolumn{2}{|c|}{0.133333333} \\
\hline 5 & Koefisien Tenaga Kerja Langsung & $\mathrm{E}=\mathrm{C} / \mathrm{B}$ & \multicolumn{2}{|c|}{0.0096} \\
\hline 6 & Harga Output VCO & $\mathrm{F} \quad(\mathrm{Rp} / \mathrm{kg})$ & $\mathrm{Rp}$ & $91,000.00$ \\
\hline 7 & $\begin{array}{l}\text { Upah Rata-rata Tenaga Kerja } \\
\text { Pendapatan dan Keuntungan }\end{array}$ & $\begin{array}{l}\mathrm{G}(\mathrm{Rp} / \mathrm{HOK} / \text { siklus }) \\
\mathrm{Rp} / \mathrm{kg} \text { bahan baku }\end{array}$ & $\mathrm{Rp}$ & $100,000.00$ \\
\hline 8 & Harga Bahan Baku & $\mathrm{H}$ & $\mathrm{Rp}$ & $2,000.00$ \\
\hline 9 & Sumbangan Input Lain & I & $\mathrm{Rp}$ & $5,300.00$ \\
\hline 10 & Nilai Output & $\mathrm{J}=\mathrm{DxF}$ & $\mathrm{Rp}$ & $12,133.33$ \\
\hline \multirow[t]{2}{*}{11} & Nilai Tambah & $\mathrm{K}=\mathrm{J}-\mathrm{H}-\mathrm{I}$ & \multirow[t]{2}{*}{$\mathrm{Rp}$} & $4,833.33$ \\
\hline & Rasio Nilai Tambah & $\mathrm{L}(\%)=(\mathrm{K} / \mathrm{J}) \times 100 \%$ & & $40 \%$ \\
\hline \multirow{2}{*}{12} & Imbalan Tenaga Kerja & $\mathrm{M}=\mathrm{EX} \mathrm{X}$ & \multirow[t]{2}{*}{$\mathrm{Rp}$} & 960.00 \\
\hline & Bagian Tenaga Kerja & $\mathrm{N}(\%)=(\mathrm{M} / \mathrm{K}) \times 100 \%$ & & $20 \%$ \\
\hline \multirow[t]{2}{*}{13} & Keuntungan & $\mathrm{O}=\mathrm{K}-\mathrm{M}$ & \multirow[t]{2}{*}{$\mathrm{Rp}$} & $3,873.33$ \\
\hline & Tingkat Keuntungan & $\mathrm{P}(\%)=(\mathrm{O} / \mathrm{K}) \times 100 \%$ & & $80 \%$ \\
\hline \multirow{2}{*}{14} & Marjin & $\mathrm{Q}=\mathrm{J}-\mathrm{H}$ & \multirow[t]{4}{*}{$\mathrm{Rp}$} & $10,133.33$ \\
\hline & Pendapatan Tenaga Kerja Langsung & $\mathrm{R}(\%)=(\mathrm{M} / \mathrm{Q}) \times 100 \%$ & & $9 \%$ \\
\hline \multirow[t]{2}{*}{15} & Sumbangan Input Lain & $\mathrm{S}(\%)=(\mathrm{I} / \mathrm{Q}) \times 100 \%$ & & $52 \%$ \\
\hline & Keuntungan Perusahaan & $\mathrm{T}(\%)=(\mathrm{O} / \mathrm{Q}) \times 100 \%$ & & $38 \%$ \\
\hline
\end{tabular}

Jumlah hasil tersebut menunjukkan nilai tambah VCO yang lumayan rendah, hal ini disebabkan oleh sumbangan input lain di tingkat perusahaan cukup tinggi. Penyebab utamanya adalah biaya transportasi dari Nias Selatan ke Pelabuhan Internasional Belawan yang cukup tinggi, rata-rata $\mathrm{Rp} 2.000 / \mathrm{kg}$. Selain itu, harga jual yang termasuk rendah karena produk VCO produksi CV Ononiha Oil sebagian besar dijual dalam bentuk grosir (wholesale) ke perusahaan lain di luar negeri untuk selanjutnya dikemas oleh pihak pembeli sesuai merk dan standarisasi di negara tujuan.

Data lain yang dapat mempengaruhi pada nilai tambah adalah nilai output. Nilai output merupakan faktor konversi dikalikan harga output, nilai output adalah harga pokok dari VCO untuk setiap bahan baku kelapa yang digunakan di dalam pengolahan kelapa. Ratarata nilai output VCO dalam perusahaan CV Ononiha Oil berjumlah Rp 12.133/kg di dalam satu siklus produksi, nilai output ini kemudian dialokasikan untuk bahan baku kelapa sebesar Rp 2.000, dan rata-rata harga input lain sebesar Rp 5,300.

\section{Analisis Nilai Tambah VCO di Tingkat Petani Pengolah Kelapa Menjadi VCO}

Dari hasil analisis dapat diketahui bahwa rata-rata nilai tambah pengolahan kelapa menjadi VCO di tingkat petani, diciptakan dari pengolahan $1 \mathrm{~kg}$ bahan baku daging kelapa menjadi VCO adalah sebesar Rp 9.522. Hasil itu menunjukkan nilai tambah VCO yang cukup tinggi. Nilai tambah tersebut masih merupakan nilai tambah kotor, karena masih mengandung imbalan tenaga kerja per $\mathrm{kg}$ bahan baku kelapa. Imbalan tenaga kerja merupakan pendapatan yang diterima sebagai upah tenaga kerja dari setiap pengolahan satu kg kelapa menjadi VCO.

Nilai output sangat mempengaruhi untuk nilai tambah, dan merupakan harga pokok dari VCO untuk setiap bahan baku kelapa yang digunakan di dalam pengolahan kelapa. Berdasarkan Tabel 2, nilai output di tingkat petani termasuk nilai yang tinggi dan mempengaruhi untuk nilai tambah menjadi tinggi juga. Dengan nilai output Rp 16.000 per $\mathrm{kg}$, nilai output ini kemudian dialokasikan untuk bahan baku kelapa sebesar Rp 2.998 per $\mathrm{kg}$, dan rata-rata sumbangan input lain sebesar Rp 3.479, sisanya adalah Nilai Tambah sebesar Rp 9.522. Sumbangan input lain di tingkat petani termasuk rendah dengan dampak di nilai tambah yang tetap tinggi. 
Tabel 2. Rata-rata nilai tambah petani pengolah kelapa menjadi VCO

\begin{tabular}{cllr}
\hline No & \multicolumn{1}{c}{ Variabel } & \multicolumn{1}{c}{ Satuan } & \multicolumn{1}{c}{ Nilai } \\
\hline 1 & Output VCO & $\mathrm{A}$ & 8 \\
2 & Input Bahan Baku & $\mathrm{B}$ & 59 \\
3 & Input Tenaga Kerja & $\mathrm{C}$ & 2 \\
4 & Faktor Konversi VCO & $\mathrm{D}=\mathrm{A} / \mathrm{B}$ & 0.14 \\
5 & Koefisien Tenaga Kerja Langsung & $\mathrm{E}=\mathrm{C} / \mathrm{B}$ & 0.03 \\
6 & Harga Output VCO & $\mathrm{F}$ & $\mathrm{Rp} 118,000$ \\
7 & Upah Rata-rata Tenaga Kerja & $\mathrm{G}$ & $\mathrm{Rp} 100,000$ \\
& Pendapatan dan Keuntungan (Rp/kg) & & \\
8 & Harga Bahan Baku & $\mathrm{H}$ & $\mathrm{Rp} 2,999$ \\
9 & Sumbangan Input Lain & $\mathrm{I}$ & $\mathrm{Rp} 3,479$ \\
10 & Nilai Output & $\mathrm{J}=\mathrm{DxF}$ & $\mathrm{Rp} 16,000$ \\
11 & Nilai Tambah & $\mathrm{K}=\mathrm{J}-\mathrm{H}-\mathrm{I}$ & $\mathrm{Rp} 9,522$ \\
& Rasio Nilai Tambah & $\mathrm{L}(\%)=(\mathrm{K} / \mathrm{J}) \times 100 \%$ & $60 \%$ \\
12 & Imbalan Tenaga Kerja & $\mathrm{M}=\mathrm{E} \mathrm{X} \mathrm{G}$ & $\mathrm{Rp} 3,390$ \\
& Bagian Tenaga Kerja & $\mathrm{N}(\%)=(\mathrm{M} / \mathrm{K}) \times 100 \%$ & $36 \%$ \\
13 & Keuntungan & $\mathrm{O}=\mathrm{K}-\mathrm{M}(\mathrm{kg})$ & $\mathrm{Rp} 6,132$ \\
& Tingkat Keuntungan & $\mathrm{P}(\%)=(\mathrm{O} / \mathrm{K}) \times 100 \%$ & $64 \%$ \\
14 & Marjin & $\mathrm{Q}=\mathrm{J}-\mathrm{H}(\mathrm{kg})$ & $\mathrm{Rp} 13,001$ \\
& Pendapatan Tenaga Kerja Langsung & $\mathrm{R}(\%)=(\mathrm{M} / \mathrm{Q}) \times 100 \%$ & $26 \%$ \\
15 & Sumbangan Input Lain & $\mathrm{S}(\%)=(\mathrm{I} / \mathrm{Q}) \times 100 \%$ & $27 \%$ \\
& Keuntungan Rumah Tangga & $\mathrm{T}(\%)=(\mathrm{O} / \mathrm{Q}) \times 100 \%$ & $47 \%$ \\
\hline
\end{tabular}

\section{Perbandingan Nilai Tambah VCO Antara Perusahaan dan Rumah Tangga Petani}

Berdasarkan analisis nilai tambah kelapa menjadi VCO pada perusahaan CV Ononiha Oil dan rata-rata rumah tangga petani pengolah, menunjukkan bahwa nilai tambah kelapa menjadi VCO lebih tinggi berada di tingkat petani pengolah kelapa yaitu rata-rata sebesar Rp 9.522 dibandingkan dengan nilai tambah pada perusahaan CV Ononiha Oil yang hanya sebesar Rp 4.833 .

Hal tersebut dikarenakan nilai output di tingkat petani lebih tinggi yakni rata-rata sebesar $\mathrm{Rp} 16.000$ dibandingkan dengan nilai output di tingkat perusahaan sebesar Rp 12.133 karena harga output di tingkat petani lebih tinggi. Walaupun untuk harga bahan baku di tingkat petani memiliki harga yang lebih mahal daripada di tingkat perusahaan, harga bahan baku di tingkat petani sebesar Rp $2.998 \mathrm{~kg}$ daging kelapa, sementara harga bahan baku di tingkat perusahaan CV Ononiha Oil sebesar Rp 2.000. Namun sumbangan input lain di tingkat petani jauh lebih rendah yakni rata-rata sebesar Rp 3.479 dibandingkan dengan sumbangan input lain di perusahaan CV Ononiha Oil sebesar Rp 5.300, karena ongkos transportasi dari perusahaan sampai Pelabuhan Internasional Belawan.

\section{Imbalan Tenaga Kerja VCO}

Imbalan tenaga kerja adalah segala kompensasi yang diterima oleh seseorang sebagai balas jasa untuk kerja mereka. Di dalam penelitian ini ada dua jenis pembayaran, pembayaran karyawan perusahaan CV Ononiha Oil secara langsung dalam bentuk upah per hari kerja. Sedangkan petani pengolah kelapa menjadi VCO yang kerja untuk diri-sendiri (self 
employed) akan dihitung berdasarkan Hari Orang Kerja (HOK) daerah sebesar Rp 100.000, sesuai dengan Upah Minimum Kabupaten (UMK) Nias Selatan.

\section{Imbalan Tenaga Kerja VCO di Tingkat Perusahaan}

Hasil analisis imbalan tenaga kerja, yang dapat dilihat pada Tabel 1, menunjukan bahwa imbalan tenaga kerja sebesar Rp 960 per kg, dan memiliki bagian tenaga kerja rata-rata sebesar hanya $14 \%$ dari total pendapatan yang dihasilkan dari perusahaan, masih termasuk nilai yang rendah. Menurut Second Wind Consultants (2019), jika perusahaan menghabiskan dibawah 30\% dari pendapatan kotor perusahaan sendiri untuk upah tenaga kerja, bisnis tersebut kemungkinan besar akan bertahan.

Tenaga kerja yang diperlukan dalam satu proses produksi di perusahaan CV Ononiha Oil merupakan tenaga kerja harian yang dipekerjakan saat diperlukan. Pada perusahaan CV Ononiha Oil selama satu hari melakukan 12,5 siklus proses produksi kelapa menjadi VCO dengan upah tenaga kerja sebesar Rp 100.000 per HOK. Sehingga dengan demikian, input tenaga kerja baik pria maupun wanita untuk pengolahan daging kelapa menjadi VCO sebesar 1,44 HOK/siklus.

Penggunaan tenaga kerja pada perusahaan CV Ononiha Oil adalah sebanyak 18 tenaga kerja (TK), yang terdiri dari satu TK sopir, satu TK pengumpul butir kelapa, dua TK pengupas kelapa, lima TK pemarut kelapa, dua TK pengepres daging kelapa, dan delapan TK lainnya membantu dalam pekerjaan mesin.

\section{Imbalan Tenaga Kerja VCO di Tingkat Petani Pengolah Kelapa Menjadi VCO}

Imbalan tenaga kerja merupakan pendapatan untuk tenaga kerja yang bekerja di dalam proses pengolahan kelapa menjadi VCO di tingkat rumah tangga petani. Tenaga kerja yang terlibat di dalam proses rata-rata hanya satu, yang mulai dari awal proses produksi sampai kepada akhir produksi adalah petani itu sendiri, dan pengerjaannya dilakukan secara manual. Oleh sebab pengerjaanya dilakukan secara manual, petani membutuhkan waktu selama dua hari kerja dalam melakukan satu siklus proses produksi kelapa menjadi VCO.

Upah tenaga kerja di tingkat petani adalah sebesar Rp 100.000, karena petani hanya mampu melakukan satu siklus proses produksi kelapa menjadi VCO dalam dua hari, sehingga upah tenaga kerjanya adalah tetap dua HOK, yaitu Rp 200.000 per siklus produksi.

Pada Tabel 2 menunjukkan juga bahwa rata-rata imbalan tenaga kerja sebesar Rp 3.389 per kg. Dimana memiliki bagian tenaga kerja sebesar 36\% dari total pendapatan yang dihasilkan dari petani sendiri, jumlah tersebut termasuk di dalam kategori tinggi karena menghabiskan lebih dari $30 \%$ dari total pendapatan kotor petani, akan tetapi tenaga kerja tersebut adalah petani itu sendiri.

\section{Perbandingan Imbalan Tenaga Kerja VCO Antara Perusahaan dan Rumah Tangga Petani}

Berdasarkan Tabel 1 dan Tabel 2, menunjukan bahwa imbalan tenaga kerja yang lebih tinggi terdapat pada petani pengolah kelapa sebesar rata-rata $\mathrm{Rp} 3.389$, dibandingkan dengan di tingkat perusahaan sebesar Rp 960, hal ini dikarenakan koefisiensi tenaga kerja langsung petani pengolah kelapa menjadi VCO rata-rata lebih tinggi yaitu sebesar 0,03 
dibandingkan dengan perusahaan sebesar 0,0096, yang berarti walaupun di tingkat perusahaan ada lebih banyak tenaga kerja, akan tetapi di tingkat rumah tangga membutuhkan lebih banyak waktu dari satu tenaga kerja itu sendiri.

\section{Keuntungan Pengolahan Kelapa Menjadi VCO}

Keuntungan pengolah kelapa menjadi VCO di tingkat petani atau perusahaan terdiri dari nilai tambah dikurangi imbalan tenaga kerja langsung dalam satu kilogram bahan baku daging kelapa. Dengan kata lain keuntungan adalah nilai tambah yang bersih.

\section{Keuntungan Perusahaan CV Ononiha Oil}

Keuntungan yang diperoleh dari perusahaan CV Ononiha Oil dapat dilihat dari besarnya nilai tambah sebesar Rp 4.833 dikurangi imbalan tenaga kerja yang dibutuhkan per kg satu siklus proses produksi sebesar Rp 960, sehingga untuk keuntungan pengolah VCO sebesar Rp 3.873/kg satu siklus proses produksi, dengan rasio nilai tambah $86 \%$.

\section{Keuntungan Petani Pengolah Kelapa Menjadi VCO}

Keuntungan rata-rata petani pengolah kelapa menjadi VCO adalah selisih antara rata-rata nilai tambah sebesar Rp 9.522 dikurangi dari rata-rata imbalan tenaga kerja sebesar Rp 3.389. Keuntungan pengolahan kelapa menjadi VCO di tingkat rumah tangga rata-rata sebesar Rp 6.132 per kg VCO. Nilai keuntungan tersebut merupakan selisih antara nilai tambah dengan imbalan tenaga kerja, dengan demikian dapat dikatakan bahwa keuntungan ini merupakan rata-rata keuntungan besar yang diterima oleh petani pengolah kelapa menjadi VCO. Dengan rata-rata tingkat keuntungan sebesar $64 \%$ dari nilai output.

\section{Perbandingan Keuntungan Antara Perusahaan CV Ononiha Oil dan Petani Pengolah Kelapa Menjadi VCO}

Rata-rata keuntungan petani pengolah kelapa menjadi VCO, yang sebesar Rp 6.132, lebih tinggi dibandingkan keuntungan di tingkat perusahaan CV Ononiha Oil sebesar Rp 3.873. Hal ini dikarenakan nilai tambah pada tingkat petani lebih tinggi yakni sebesar Rp 9.522, daripada di tingkat perusahaan yang hanya sebesar Rp 4.833, yang dipengaruhi oleh nilai tinggi sumbangan input lain dari perusahaan, namun imbalan tenaga kerja perusahaan lebih rendah.

Walaupun tingkat keuntungan perusahaan CV Ononiha Oil termasuk dalam kategori yang tinggi sebesar $80 \%$, dan termasuk lebih tinggi daripada tingkat keuntungan di tingkat petani pengolah kelapa menjadi VCO, sebesar 64\%. Hal tersebut dikarenakan perusahaan CV Ononiha Oil memiliki siklus produksi yang lebih banyak daripada petani pengolah kelapa menjadi VCO, yaitu sebesar 12,5 siklus proses produksi dalam satu hari kerja di tingkat perusahan, daripada di tingkat petani yang membutuhkan dua hari kerja untuk selesaikan satu siklus produksi.

Tingkat keuntungan petani pengolah kelapa menjadi VCO masih termasuk dalam kategori yang cukup tinggi, namun petani hanya mampu memproduksi satu siklus proses produksi kelapa menjadi VCO yang hanya sebesar $8 \mathrm{~kg}$ VCO di dalam dua hari kerja. Dikarenakan 
imbalan tenaga kerja di tingkat petani pengolah kelapa menjadi VCO lebih tinggi daripada imbalan tenaga kerja di tingkat perusahaan.

\section{Kendala-Kendala Pengolahan Kelapa Menjadi VCO dan Pemasaran}

Kendala merupakan suatu realitas yang membatasi apa yang bisa dicapai. Kendala-kendala di dalam proses pengolahan kelapa menjadi VCO dan Pemasaran di tingkat perusahaan dan petani pengolah, merupakan kebanyakan penghambat yang berbeda, dengan beberapa kendala yang sama.

\section{Kendala-Kendala Perusahaan CV Ononiha Oil}

Selama melakukan penelitian di perusahaan CV Ononiha Oil, beberapa kendala yang dihadapi oleh perusahaan akan dijabarkan dalam beberapa hal. Kendala tersebut antara lain adalah kekurangan tim manajer untuk fungsi-fungsi yang kunci. Selain memiliki posisi sebagai pemilik perusahaan CV Ononiha Oil, pemilik juga merangkap sebagai operational manager, marketing manager, financial manager dan sales manager. Tugas dan fungsi dari setiap bagian divisi yang ada tidak dapat berjalan dengan baik karena semua manajer divisi yang ada di perusahaan dipegang oleh satu orang sendiri, one man show. Seperti misalnya, pada saat peneliti ke perusahaan CV Ononiha Oil menemukan bahwa perusahaan sedang berhenti melakukan produksi VCO dikarenakan tidak adanya permintaan dari pasar. Hal tersebut berarti, fungsi pemasaran di perusahaan tidak berjalan dengan maksimal.

Kendala lain juga berada pada kebutuhan sertifikat dari pemerintah. Perusahaan CV Ononiha Oil merasa sulit untuk memperoleh sertifikat organik karena tidak ada, badan pengelola yang mengeluarkan sertifikat tersebut di Wilayah Nias. Ketiadaan sertifikat organik menyebabkan perusahaan CV Ononiha Oil kesulitan memasarkan VCO ke pasar mancanegara.

Ongkos transportasi merupakan salah satu kendala yang berdampak paling berat pada nilai tambah. Sumbangan input lain cukup tinggi di tingkat perusahaan karena ongkos transportasi VCO dari perusahaan di Kabupaten Nias Selatan sampai di Pelabuhan Internasional Belawan mencapai jumlah rata-rata Rp 2.000 per kilogram hasil VCO. Walaupun ongkos tersebut sudah termasuk gudang selama satu bulan, di mana perusahaan CV Ononiha Oil tidak perlu membayar gudang di Medan, ongkos transportasi masih termasuk terlalu tinggi, dengan dampak berat pada keuntungan perusahaan.

\section{Kendala-Kendala Petani Pengolah Kelapa Menjadi VCO}

Selama melakukan penelitian pada petani pengolah kelapa menjadi VCO, dapat diketahui beberapa kendala pada petani yang mengolah VCO yaitu: kurang tim manajemen, sertifikat organic, namun ada juga kendala-kendala lain; petani hanya mampu memasarkan VCO ke pasar lokal yang sangat terbatas, kurang secara ukuran pasar lokal, dan secara finansial dari target pasar tersebut. Petani pengolah belum mampu mencapai pemasaran yang maksimal seperti toko-toko, supermarket, pasar mancanegara, dan di luar kabupaten sendiri atau ke luar negeri, karena belum memiliki sertifikat dari PIRT (Pangan Industri Rumah Tangga) karena sertifikat tersebut termasuk mahal dan persyaratanya sulit dipenuhi. Pasar lokal yang dimaksud disini adalah penjualan yang hanya bisa dipasarkan ke tetanggatetangga petani yang ada di Kabupaten Nias Selatan saja. 
Petani juga terkendala pada ketersediaan mesin pengolah VCO yang masih kurang dari segi kuantitas dan belum modern, seperti misalnya dalam pengepresan daging kelapa. Petani masih menggunakan kain dengan bantuan tenaga tangan, dan dalam penggunaan mesin pemarut kelapa yang belum berasal dari bahan yang terbaik, seperti stainless steel yang tidak mudah berkarat. Selain itu petani yang tidak memiliki kebun sendiri juga terkendala pada harga beli bahan baku. Disisi lain harga jual VCO hasil produksi rumah tangga juga tergolong murah.

\section{Perbandingan Kendala-Kendala Antara Perusahaan CV Ononiha Oil dan Petani Pengolah Kelapa Menjadi VCO}

Dari penjelasan kendala-kendala dari dua jenis responden tersebut, dapat diketahui bahwa kendala-kendala yang terdapat pada perusahaan CV Ononiha Oil adalah dari segi manajemen dan pemasaran yang kurang efisien, tidak adanya orang atau tim khusus yang bisa mempromosikan hasil produksi secara efisien menjadi kendala utama. Pemilik masih memegang sendiri seluruh aktivitas manajerial dalam perusahaan (one man show). Hal ini menyebabkan kurang optimalnya manajemen yang dapat dilakukan. Sulitnya memperoleh sertifikat organik juga menjadi kendala di tingkat perusahaan.

Sementara kendala pada tingkat petani pengolah kelapa menjadi VCO selain kendalakendala yang dihadapi perusahaan, ada juga dari segi ketersediaan mesin dan keterbatasan pemasaran. Kendala kurang izin dari lembaga seperti PIRT (Pangan Industri Rumah Tangga) pada tingkat petani selain kesulitan karena berada di desa yang jauh dari ibu kota provinsi, juga kurangnya alat dan mesin yang seharusnya dipakai untuk memenuhi standar badan seperti PIRT.

Kesulitan untuk mendapatkan sertifikat PIRT/BPOM atau sertifikat organik berada pada tingkat perusahaan dan pada tingkat petani pengolah. Komite Akreditasi Nasional (KAN) merupakan lembaga yang memberikan sertifikat organik, akreditasi tersebut diberikan melalui Lembaga Sertifikasi Organik (LSO), yang berada di Jakarta. Lembaga Sertifikasi Organik dapat memenuhi persyaratan dalam SNI ISO/IEC 17065:2012. Sertifikasi organik adalah sarana untuk memberikan jaminan bahwa produk organik memenuhi persyaratan yang ditentukan dalam standar dan dokumen normatif lainnya melalui kegiatan inspeksi yang dilakukan oleh Lembaga Sertifikasi Organik.

Untuk memenuhi persyaratan organik, VCO harus memenuhi sifat kimia dan fisika seperti yang ditentukan pada berikut: Komposisi asam lemak produk harus berada dalam kisaran yang sesuai, seperti berikutnya: Volatile matter; Produk mengandung $<0,2 \%$ bahan volatil pada $105^{\circ} \mathrm{C}$; Residu pestisida: Produk harus bebas dari residu pestisida; Lainnya: Produk harus memenuhi batas maksimum sebagai berikut: Besi (Fe): $<5,0 \mathrm{mg} / \mathrm{kg}$; Tembaga: $<0,4$ mg / kg; Timbal: <0,1 mg / kg; Arsenik: <0,1 mg / kg. Produk VCO harus diproses dan dikemas dalam kondisi higienis di tempat yang dilisensikan sesuai dengan peraturan kesehatan masyarakat yang saat ini diberlakukan.

\section{SIMPULAN DAN SARAN}

\section{Simpulan}

Hasil penelitian dapat disimpulkan bahwa (1) Nilai tambah, imbalan tenaga kerja, dan keuntungan tertinggi terdapat sema pada tingkat petani. (2) Kendala-kendala yang 
menghambat Perusahaan CV Ononiha Oil lebih dari segi manajemen dan pemasaran yang kurang efisien, belum adanya orang atau tim khusus untuk mempromosikan hasil produksi secara efisien, pemilik masih melakukan sendiri seluruh aktivitas manajerial dalam perusahaan (one man show), serta belum memperoleh sertifikat organik. Sedangkan petani pengolah kelapa menjadi VCO di Kabupaten Nias Selatan mengalami lebih banyak kendala, yaitu: belum memproduksi bahan baku sendiri, mesin sederhana dan cepat berkarat, kekurangan pasar lokal dan belum adanya izin dari PIRT. Untuk dapat masuk ke pasar yang lebih luas seperti took-toko, supermarket atau pasar luar kabupaten sendiri.

\section{Saran}

Berdasarkan hasil penelitian dan kesimpulan maka dapat dibagi saran sebagai berikut (1) Penambahan nilai di dalam proses pengolahan kelapa menjadi VCO sangat tergantung kepada permintaan pasar, oleh karena itu perusahaan harus memiliki manajer atau tim marketing yang akan memfokuskan kepada pemasaran VCOnya. Perusahaan juga memerlukan bermitra dengan perusahaan lain atau pemerintah Nias Selatan serta Kabupaten Nias, yang memerlukan transportasi juga, sehingga ongkos transportasi bisa dapat direndahkan. Serta mitra dengan petani-petani pengolah, untuk membeli hasil VCO petani pengolah, dengan proses standarisasi dan pengecekkan. (2) Kepada petani pengolah kelapa menjadi VCO, harus tetap mempromosikan kepada pasar lokal karena keuntungan masih cukup baik, dan usahakan memiliki izin PIRT, dengan membentuk koperasi atau kelompok tani, dimana semua VCO yang diproduksi bisa dapat sertifikasi, dan masuk pasar lebih luas. Petani pengolah memerlukan alat dan mesin yang lebih tepat dan efisien untuk memenuhi persyaratan organik, serta memaksimalkan produksi. Kolaborasi antara perusahaan dan petani serta pemerintah di bidang promosi melalui pameran untuk memperkuat pemasaran dalam negeri. Kabupaten Nias Selatan sudah mulai terkenal oleh wisatawan, dengan mitra Kelompok tani dan perusahaan dapat membangun agrowisata desa organik dimana wisatawan bisa datang membeli VCO dan menguatkan pasar lokal, selain itu rumah petani bisa digunakan sebagai penginapan untuk meningkatkan pendapatan petani.

\section{UCAPAN TERIMA KASIH}

Penulis mengucapkan terimakasih kepada pemilik perusahaan CV Ononiha, seluruh informan dan petani responden, serta Dosen Fakultas Pertanian Universitas Udayana yang turut serta membantu dalam penyelesaian penelitian ini.

\section{DAFTAR PUSTAKA}

BPS, Badan Pusat Statistik, 2018. Katalog Statistik Kabupaten Nias Selatan 2018. BPS Kabupaten Nias Selatan. Nomor ISBN : 978-602-5537-48-6.

Direktorat Jenderal Perkebunan. 2016. Statistik Perkebunan Indonesia Komoditas Kelapa 2014 - 2016. Jakarta: Direktorat Jenderal Perkebunan.

Hayami, Kawagoe, Morooka, dan Siregar, 1987. Agricultural Marketing and Processing in Upland Java A Perspective from A Sunda Village. Bogor: CGPRT Centre.

Nester. 2017. Virgin Coconut Oil Market: Global Demand Analysis \& Opportunity Outlook 2023.https://www.researchnester.com/reports/virgin-coconut-oil-market-global- 
demand-analysis-opportunity-outlook-2023/253. Diakses pada tanggal 05 April 2019.

Second Wind Consultants, 2019. What percent of your revenue should be spent on payroll?. https://secondwindconsultants.com/resources/what-percent-of-yourrevenue-should-be-spent-on-payroll/. Diaksess pada tanggal 27 September 2019. 